\title{
Characterization of Fish Creek, Teton County, Wyoming, 2004-08
}

\section{Introduction}

Fish Creek, a tributary to the Snake River, is about 15 river miles long and is located in Teton County in western Wyoming near the town of Wilson (fig. 1). Public concern about nuisance growths of aquatic plants in Fish Creek has been increasing since the early 2000s. To address this concern, the U.S. Geological Survey, in cooperation with the Teton Conservation District, began studying Fish Creek in 2004 to describe the hydrology of the creek and later (2007-08) to characterize the water quality and the biological communities. The purpose of this fact sheet is to summarize the study results from 2004 to 2008.

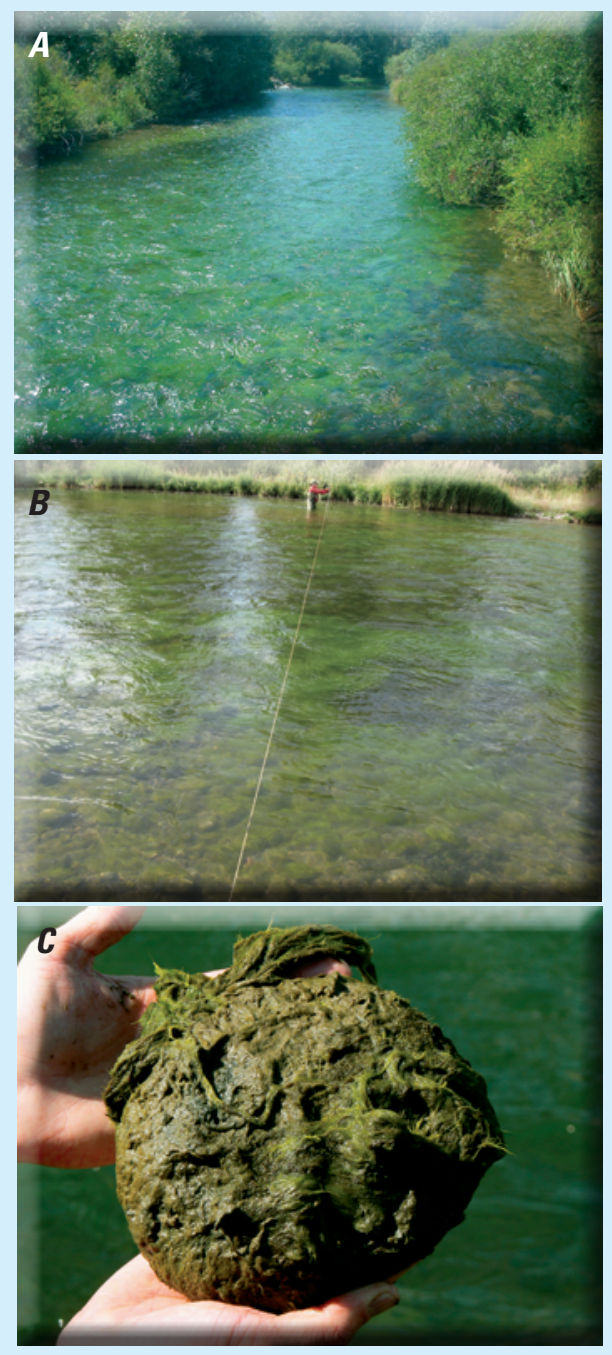

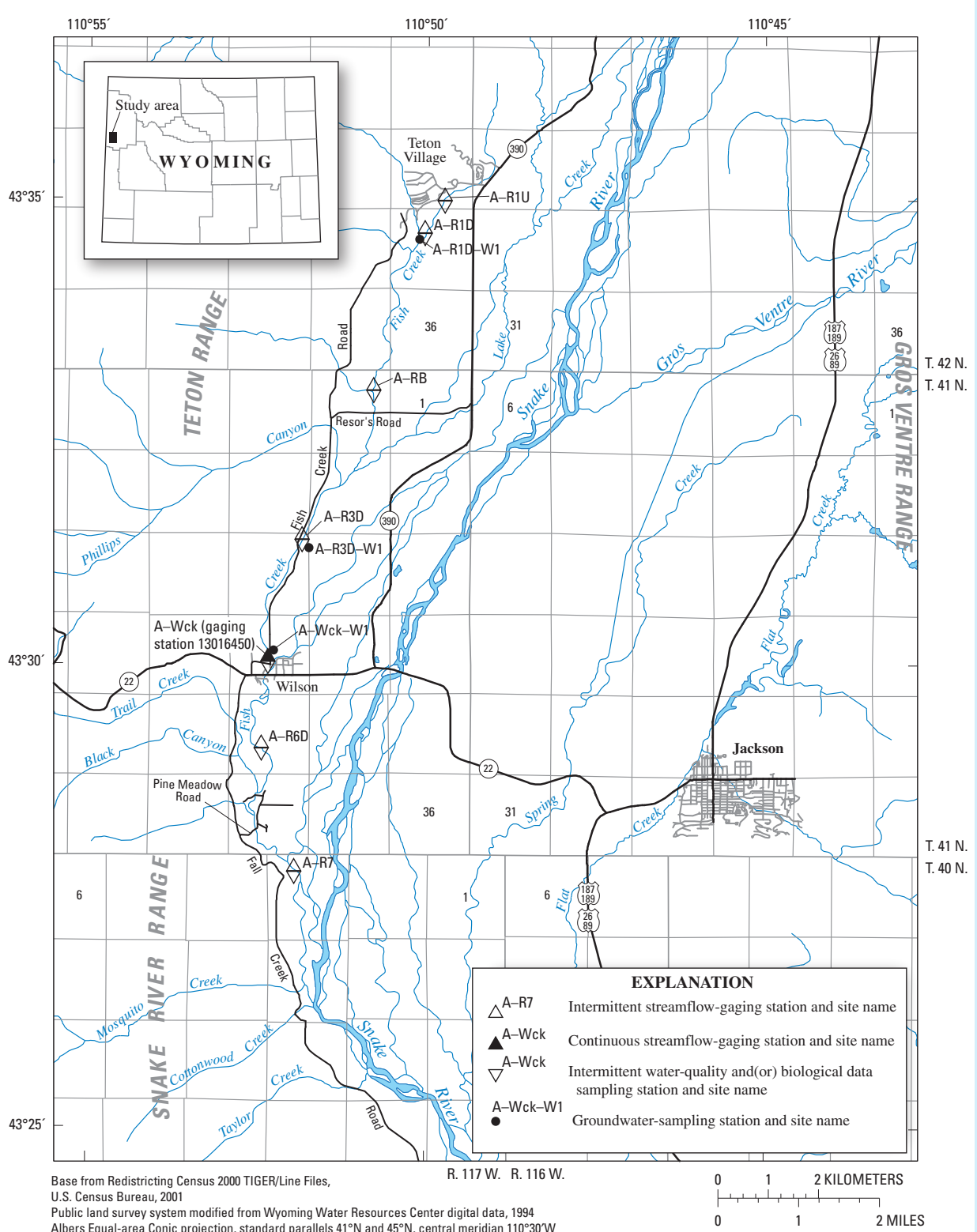

Figure 1. Fish Creek study area and surface-water and groundwater sampling sites.

(A) Green hue in stream primarily from the algae Cladophora at site A-Wck, Fish Creek at Wilson, July 2007. (Photograph by David A. Peterson.)

(B) Macrophytes and macroalgae on the streambed in Fish Creek at site A-R7, August 2008. (Photograph by Jerrod D. Wheeler.)

(C) Typical algal growth on cobbles from Fish Creek at site A-Wck during August 2008. (Photograph by Cheryl A. Eddy-Miller.) 


\section{Hydrology}

The interaction between surface water and groundwater in the Fish Creek area was the focus of two separate studies: a seepage run study (Wheeler and Eddy-Miller, 2005) and a continuous groundwater/surface-water interaction study (EddyMiller and others, 2009). During the seepage run, conducted in August and November 2004, flows were measured in the creek at six sections to describe where the creek gained water from, or lost water to, groundwater. A summary of the results of the seepage run are shown in figure 2 .

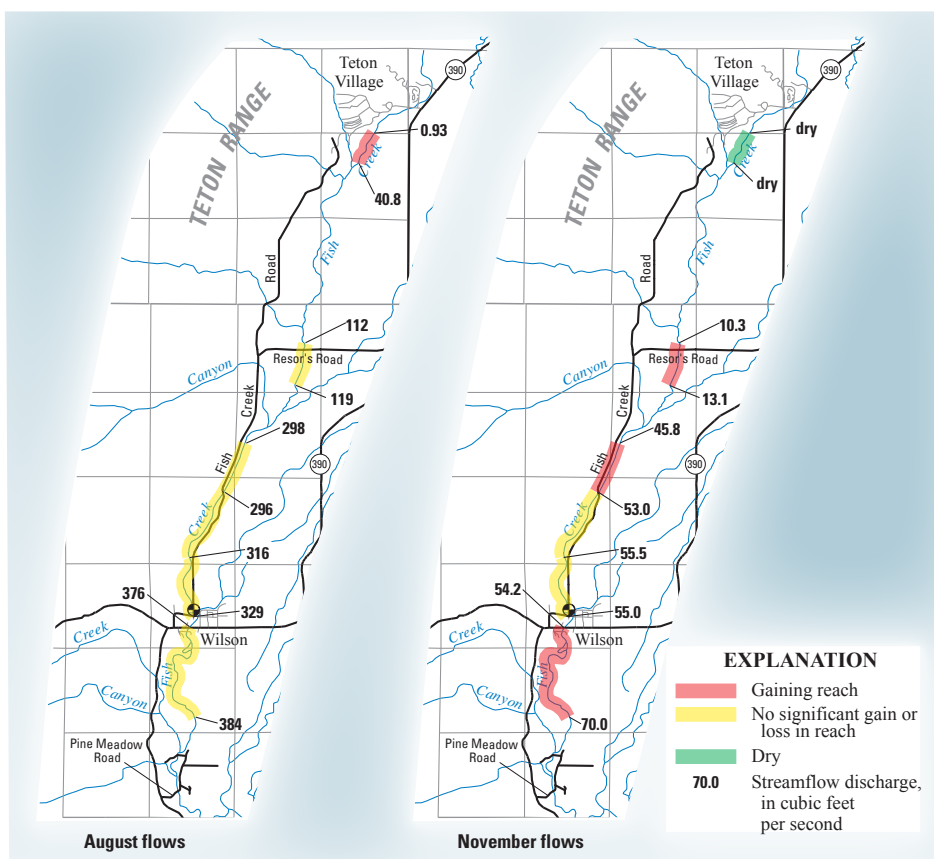

Figure 2. Seepage run results from August and November 2004 show Fish Creek is either gaining water from groundwater or neither gaining water from nor losing water to groundwater.

The seepage run showed how Fish Creek and the nearby groundwater interacted at two specific times. To determine the interaction between surface water and groundwater on a yearly basis, an 18-month-long study using heat as a tracer began in 2005 (Eddy-Miller and others, 2009).

The results of both studies showed that:

- Flow in Fish Creek is a function of runoff from snowmelt and precipitation, irrigation return flows, tributary streams, and groundwater input.

\section{Near Teton Village}

- Fish Creek near Teton Village typically had water in the channel from late April/mid-May until mid- to late September.

- Flow in Fish Creek in the Teton Village area was in large part due to inputs of groundwater to the creek channel.

\section{Upstream from Lake Creek Confluence}

- Fish Creek becomes a perennial stream just upstream from the confluence with Lake Creek.
- High flows in the creek in this area were due to a large increase in groundwater input to the creek that occurred from spring through mid-July in 2005 and 2006.

\section{At Wilson}

- The flow in Fish Creek at Wilson is a combination of upstream flow in the creek, tributary inputs, and a smaller, but steady, year-round groundwater input.

- At Wilson, a U.S. Geological Survey streamflow-gaging station (13016450) has recorded flow in the river every 15 minutes since 1994. These data can be accessed at http://waterdata.usgs.gov/nwis/uv/?site $n o=13016450 \&$ agency_cd $=U S G S$.

- Data from this streamflow-gaging station show:

- Average flow in the winter is about 40 cubic feet per second $\left(\mathrm{ft}^{3} / \mathrm{s}\right)$.

- The highest summer flows typically occur in June and average around $600 \mathrm{ft}^{3} / \mathrm{s}$ during the days with highest flows.

- The highest flow on record $\left(1,430 \mathrm{ft}^{3} / \mathrm{s}\right)$ occurred on June 8, 1997.

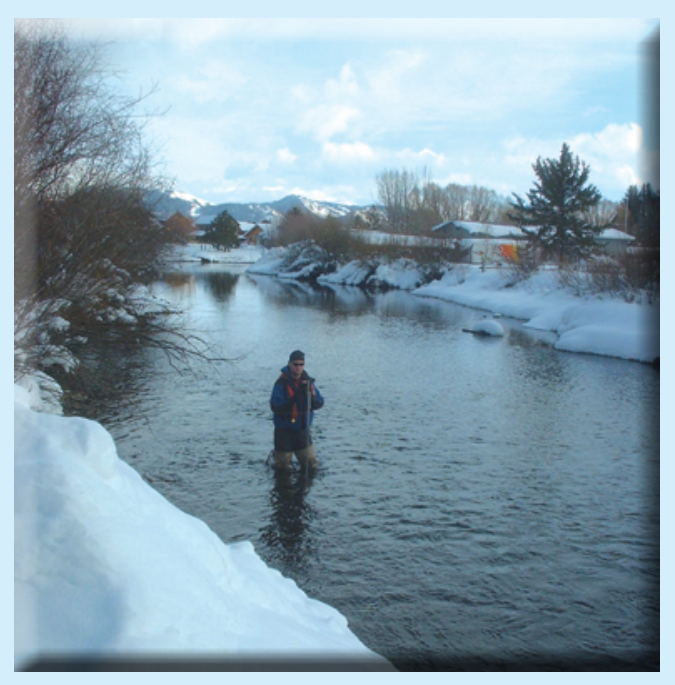

Wintertime streamflow measurement at Fish Creek at Wilson site. (Photograph by Cheryl A. Eddy-Miller.)

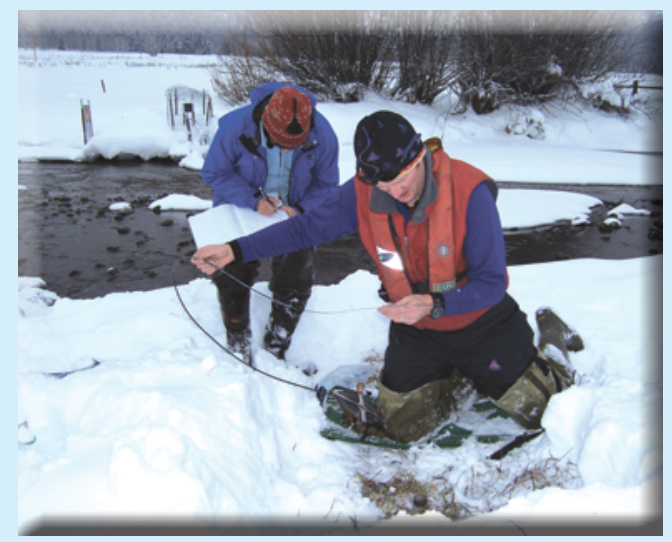

Measuring water levels at well cross section. (Photograph by Rodney R. Caldwell.) 


\section{Water Quality and Biological Communities}

During 2007-08, samples were collected and analyzed to characterize the water quality and biological communities of Fish Creek (Eddy-Miller and others, in press). Stream temperature, $\mathrm{pH}$, specific conductance, and dissolved oxygen were measured and samples for analyses of nutrients were collected to describe the water quality of Fish Creek and nearby groundwater. Algae, macrophytes (rooted aquatic plants), and benthic macroinvertebrates (aquatic insects and others that live on the streambed) were the biological communities studied. Although 2 years of data are not sufficient to statistically define ecological relations, the data from eight sampling events during the 2 years were used to characterize the stream.

\section{Water-Quality Results:}

- Concentrations of nitrogen and phosphorus, which are the most important nutrients for algal growth, were analyzed to help describe the water quality in the creek. All waterquality data can be accessed at http://wy.water.usgs.gov/ projects/fishcreek/communities.htm.

- Concentrations of nutrients are higher in the groundwater than in Fish Creek. Because it is known that a large amount of water in the creek originates as groundwater, one source of nutrients is the groundwater.

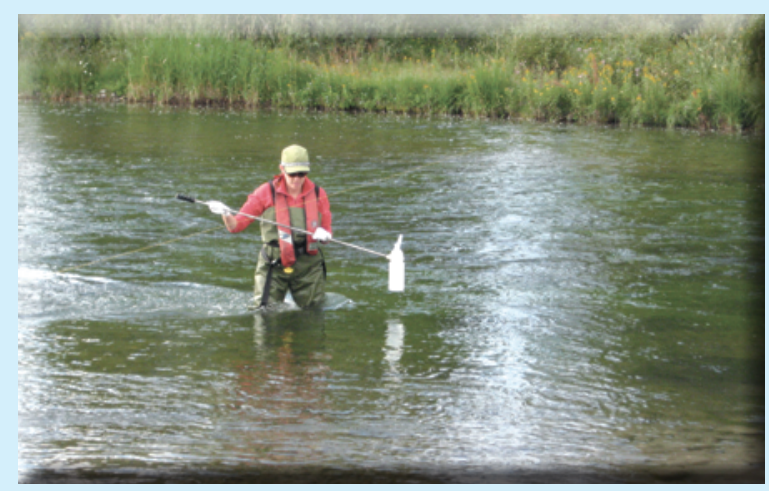

Water-quality sample collection at site A-R7. (Photograph by Jerrod D. Wheeler.)

\section{Biological Community Results}

- The amount of algae in Fish Creek (determined using chlorophyll- $a$ as an indicator) is atypical.

- The concentrations of chlorophyll- $a$ at the sites with perennial flow averaged more than 200 milligrams per square meter $\left(\mathrm{mg} / \mathrm{m}^{2}\right)$, ranging from $47 \mathrm{mg} / \mathrm{m}^{2}$ to more than $3,000 \mathrm{mg} / \mathrm{m}^{2}$ (Eddy-Miller and others, in press).

- Chlorophyll- $a$ concentrations in Fish Creek were much higher than concentrations in other area streams and rivers, which had concentrations ranging from 1.1 to $16 \mathrm{mg} / \mathrm{m}^{2}$ (Eddy-Miller and others, in press).

- Ninety percent of all chlorophyll- $a$ concentrations from Fish Creek were higher than the voluntary standard recommended by local governments in Montana $\left(100 \mathrm{mg} / \mathrm{m}^{2}\right)$ to curb nuisance growths of algae in the Clarks Fork River (Eddy-Miller and others, in press).

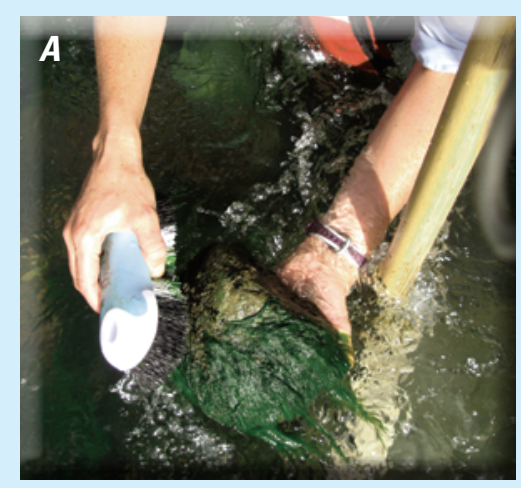

( $A$ and $B$ ) Algal growth on cobbles in Fish Creek at sites A-R3D, August 2008. (Photographs by Jerrod D. Wheeler.)

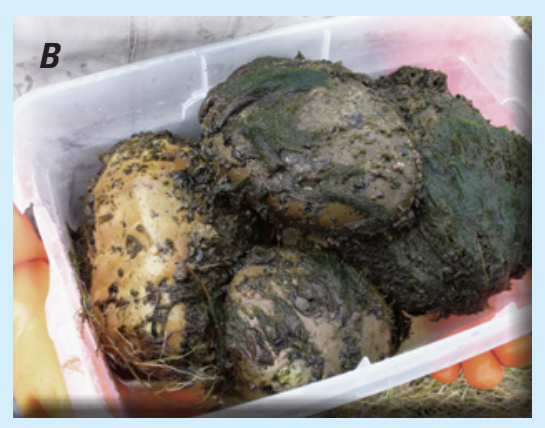

- Seasonal patterns are evident for several biological communities:

- Algae are always present in the stream, but the amount and type are different depending on the time of year.

- More caddisfly, mayfly, and stonefly larvae are found in the May samples than in the August samples (fig. 3).

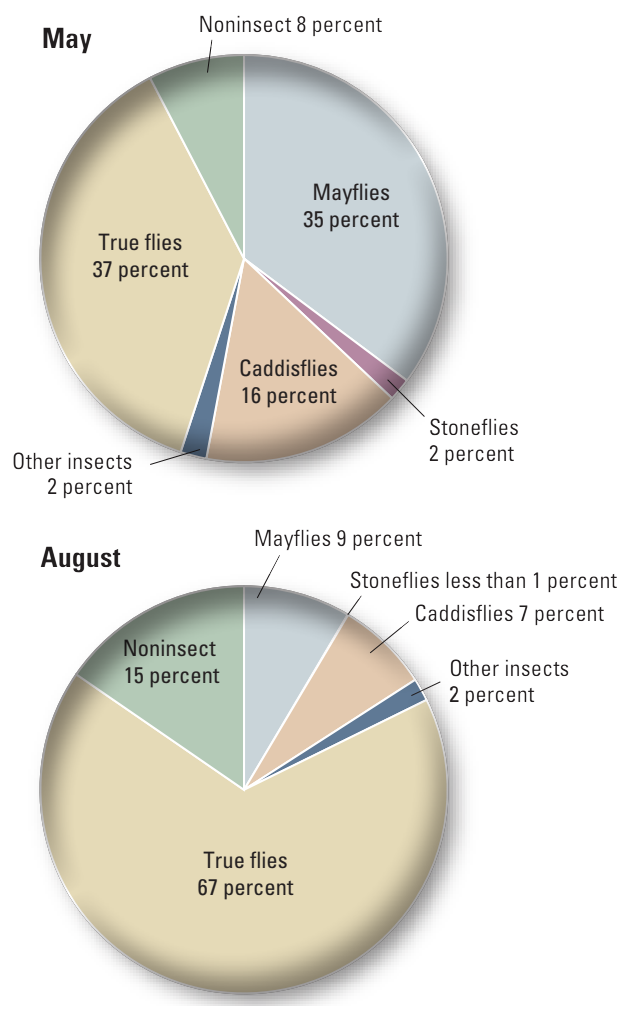

Figure 3. Average distribution of macroinvertebrates at Fish Creek sites with perennial flow show a change in distribution of species between May and August, 2007-08. 


\section{Future Work}

Continued collection of the same types of data are planned for 2010 and 2011. After the 2011 data collection, the 5 years of data can be analyzed using statistical methods to evaluate true patterns from the expected variations that occur on an annual basis. These analyses can help to determine what relations exist between the flow, water quality, aquatic plants, and macroinvertebrates. This information can then be used by interested parties to determine ways to protect Fish Creek as a productive fishery in the future.
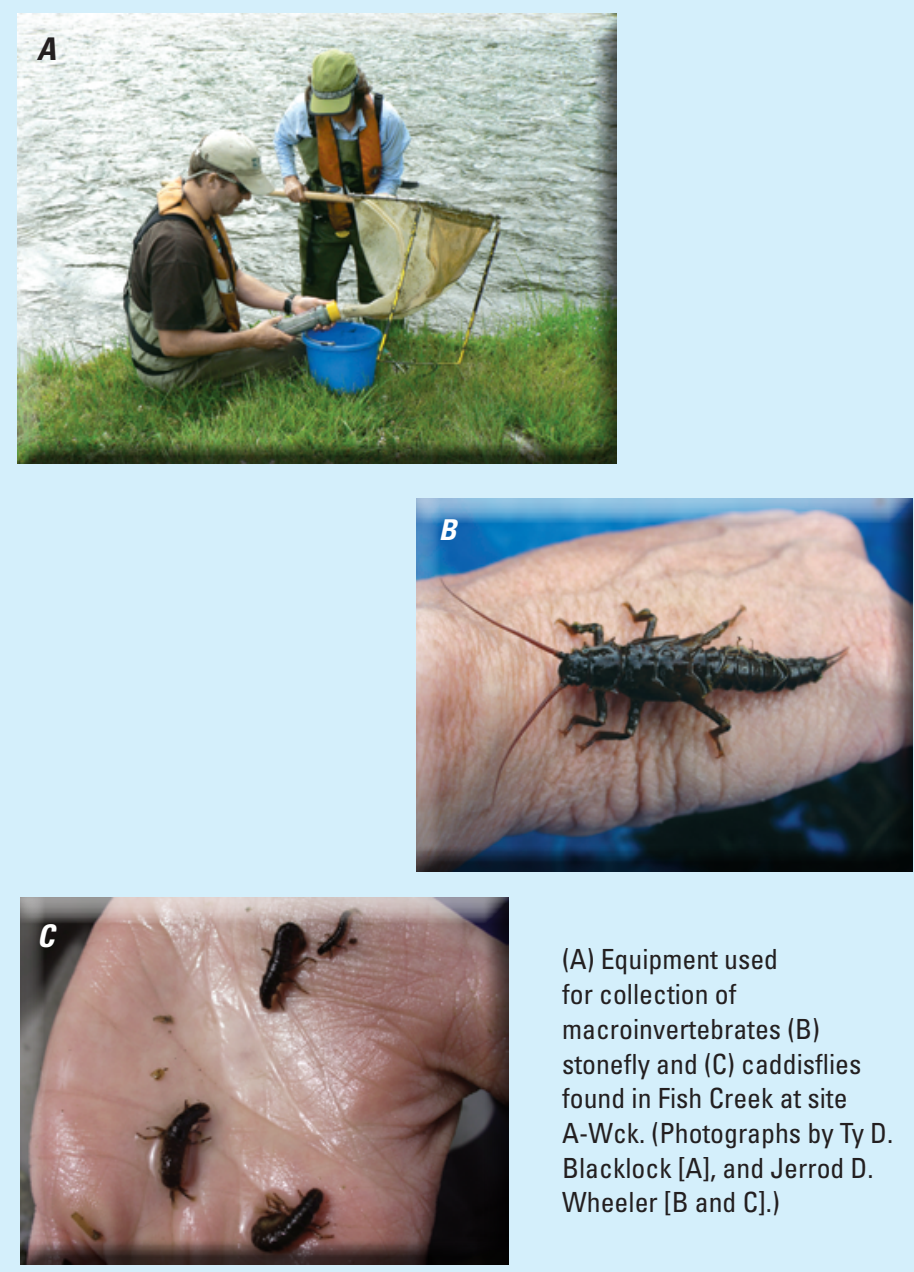

(A) Equipment used for collection of macroinvertebrates (B) stonefly and (C) caddisflies found in Fish Creek at site A-Wck. (Photographs by Ty D. Blacklock [A], and Jerrod D. Wheeler [B and C].)

\section{References Cited}

Eddy-Miller, C.A., Peterson, D.A., Wheeler, J.D., and Leemon, D.J., in press, Characterization of water quality and biological communities, Fish Creek, Teton County, Wyoming, 2007-08: U.S. Geological Survey Scientific Investigations Report 2010-5188.

Eddy-Miller, C.A., Wheeler, J.D., and Essaid, H.I., 2009, Characterization of interactions between surface water and near-stream groundwater along Fish Creek, Teton County, Wyoming, by using heat as a tracer: U.S. Geological Survey Scientific Investigations Report 2009-5160, $53 \mathrm{p}$.

Wheeler, J.D., and Eddy-Miller, C.A., 2005, Seepage investigation on selected reaches of Fish Creek, Teton County, Wyoming, 2004: U.S. Geological Survey Scientific Investigations Report 2005-5133, 15 p.

\section{For More Information: \\ Visit the USGS Wyoming Water Science Center Web site at http://wy.water.usgs.gov/projects/fishcreek/index.htm, or contact: \\ Cheryl A. Eddy-Miller \\ U.S. Geological Survey, 2617 E. Lincolnway, Suite B, Cheyenne, WY 82001, (307) 775-9167, cemiller@usgs.gov. \\ Dan Leemon \\ Teton Conservation District, P.O. Box, 1070, Jackson, WY 83001, (307) 733-2110,dan@tetonconservation.org.}

\section{By}

Cheryl A. Eddy-Miller, ${ }^{1}$ David A. Peterson, ${ }^{1}$ Jerrod D. Wheeler, ${ }^{1}$ and Daniel J. Leemon ${ }^{2}$

${ }^{1}$ U.S. Geological Survey.

${ }^{2}$ Teton Conservation District.
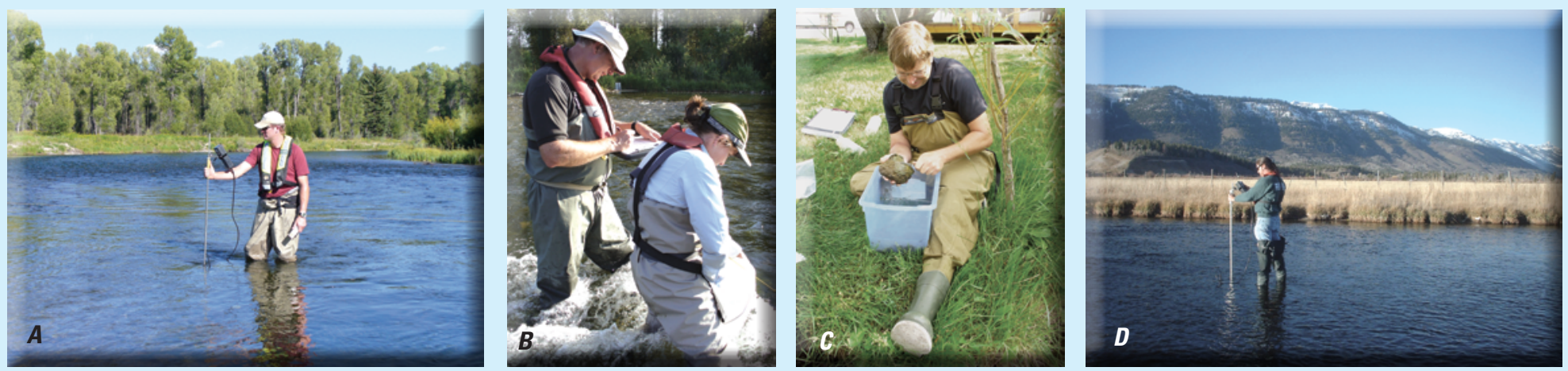

(A) Making a summer streamflow measurement at site A-R7; (B) evaluating aquatic plants; (C) collecting algal samples; and (D) making a fall streamflow measurement at site A-R6D. (Photographs by Cheryl A. Eddy-Miller [A] and Jerrod D. Wheeler [B, C, and D].) 